Uniwersytet PrzyrodniczoHumanistyczny w Siedlcach

Siedlce University of Natural Sciences and Humanities

https://bazawiedzy.uph.edu.pl

\begin{tabular}{|l|l|}
\hline Publikacja / Publication & $\begin{array}{l}\text { Distribution of classical enterotoxin genes in staphylococci from milk of cows with- } \\
\text { and without mastitis and the cowshed environment, } \\
\text { Piechota Małgorzata, Kot Barbara, Zdunek Ewa, Mitrus Joanna Małgorzata, Wicha } \\
\text { Jolanta, Wolska Marzena Katarzyna, Sachanowicz Katarzyna }\end{array}$ \\
\hline $\begin{array}{l}\text { Adres publikacji w Repozytorium } \\
\text { URL / Publication address in } \\
\text { Repository }\end{array}$ & https://bazawiedzy.uph.edu.pl/info/article/UPH38ac630fbe6a4b88b3679e8fd0c40654/ \\
\hline $\begin{array}{l}\text { Data opublikowania w Repozytorium / } \\
\text { Deposited in Repository on }\end{array}$ & 22 paź 2021 \\
\hline Rodzaj licencji / Type of licence & Attribution CC BY O \\
\hline Cytuj tę wersję / Cite this version & $\begin{array}{l}\text { Piechota Małgorzata, Kot Barbara, Zdunek Ewa, Mitrus Joanna Małgorzata, Wicha } \\
\text { Jolanta, Wolska Marzena Katarzyna, Sachanowicz Katarzyna: Distribution of } \\
\text { classical enterotoxin genes in staphylococci from milk of cows with- and without } \\
\text { mastitis and the cowshed environment, Polish Journal of Veterinary Sciences, vol. } \\
17, \text { no. 3, 2014, pp. 407-411 }\end{array}$ \\
\hline
\end{tabular}




\title{
Distribution of classical enterotoxin genes in staphylococci from milk of cows with- and without mastitis and the cowshed environment
}

\author{
M. Piechota ${ }^{1}$, B. Kot ${ }^{1}$, E. Zdunek ${ }^{1}$, J. Mitrus ${ }^{2}$, J. Wicha' ${ }^{1}$, M.K. Wolska ${ }^{1}$, \\ K. Sachanowicz ${ }^{1}$ \\ ${ }^{1}$ Department of Microbiology, Institute of Biology, Siedlce University of Natural Sciences and Humanities, \\ Bolesława Prusa 12, 08-110 Siedlce, Poland \\ ${ }^{2}$ Department of Plant Physiology and Genetics, Institute of Biology, \\ Siedlce University of Natural Sciences and Humanities, Bolesława Prusa 12, 08-110 Siedlce, Poland
}

\begin{abstract}
The aim of this study was to analyze by PCR 185 isolates of Staphylococcus from milk of cows with- and without mastitis and from the cowsheds environment for their potential ability to produce five classical staphylococcal enterotoxins. Among S. aureus isolates 8 (32\%) carried enterotoxin genes and only 2 of them had more than one gene. The enterotoxin genes were detected in $22(13.7 \%)$ coagulase-negative staphylococci (CNS) isolates, among them in 9 (11.4\%) isolates of $S$. xylosus, $5(16.7 \%)$ S. sciuri, $3(10.3 \%)$ S. epidermidis and in 5 (22.7\%) Staphylococcus spp. In some CNS 2 or 3 genes were detected simultaneously. Among the investigated enterotoxin genes, $\mathrm{sec}$ was the most prevalent (70\%). The genes encoding enterotoxin B and D were detected in $5(16.7 \%)$ and $6(20 \%)$ isolates, respectively. The lowest number of isolates had sea and see genes.

The genes encoding enterotoxins were often identified in staphylococci from milk of cows with mastitis ( $73.4 \%$ of detected genes), while only $6(20 \%)$ isolates from milk of cows without mastitis and $2(6.6 \%)$ isolates from cowshed environment were positive for enterotoxin genes.

The results showed that CNS from bovine milk, like $S$. aureus, carried enterotoxin genes and may pose a risk for public health.
\end{abstract}

Key words: coagulase-negative staphylococci, S. aureus, staphylococcal enterotoxin genes, PCR 


\section{Introduction}

Historically, $S$. aureus have been considered the most important pathogen among staphylococci causing mastitis, whereas coagulase-negative staphylococci (CNS) were considered minor pathogens (Njage et al. 2013). However, recently CNS have become a significantly predominant pathogen in bovine mastitis (Sampimon et al. 2009, Kot et al. 2012a). Similarly as $S$. aureus, CNS produce a number of virulence factors that determine the ability of adhesion, avoidance of host immune mechanisms, production of toxins and enzymes (Dinges et al. 2000). The main toxins produced by staphylococci are classified as having the characteristics of staphylococcal enterotoxins (SEs). SEs have the properties of superantigens (SAgs) and induce uncontrolled proliferation of $\mathrm{T}$ lymphocytes. Superantigen production leads to excessive secretion of cytokines and lymphokines, and consequently damage to the blood vessels, lowering blood pressure and inducing fever (Baker and Acharya 2004). The International Nomenclature Committee for Staphylococcal Superantigens developed standard nomenclature of enterotoxins according to which staphylococcal enterotoxins (SEA-SEI) show emetic activity which was confirmed in tests on primates. Other enterotoxins, marked J-V, are called the putative SEls (Staphylococcal Enterotoxin-like superantigens) because they showed no emetic properties in animal studies (Lina et al. 2004, Collery et al. 2008, Podkowik et al. 2013). Another classification of enterotoxins involves their division into classical enterotoxins (five antigenically different types of SEA, SEB, SEC, SED, SEE) and new enterotoxins (SEG-SEIV) (Bania et al. 2006, Park et al. 2011). Genes encoding staphylococcal enterotoxins may be located on plasmids, bacteriophages, transposons, or pathogenicity islands (PIs) and are transferred by horizontal gene transfer. Staphylococci present in food, showing the potential to produce enterotoxins, are serious threat to public health (Blaiotta et al. 2006). Enterotoxins SEA, SEB, SEC, SED, called classic, cause more than $90 \%$ of cases of staphylococcal food poisoning (SFP). Milk and dairy products can be a source of enterotoxic staphylococci (Orwin et al. 2001, Asao et al. 2003, Boynukara et al. 2008). Due to the growing importance of CNS as etiological agents of mastitis it is important to study the potential ability of production of enterotoxins by these bacteria.

The aim of this study was the analysis of the occurrence of classical enterotoxin genes by PCR in $\mathrm{CNS}$ and $S$. aureus isolated from milk of cows with - and without mastitis symptoms and from cowshed environmental samples.

\section{Materials and Methods}

\section{Staphylococcal isolates}

A total of 125 staphylococcal isolates from milk of cows with subclinical and clinical mastitis and 29 isolates from milk samples from cows without mastitis symptoms, as well as 31 isolates from cowshed environment, were used in this study. The diagnosis of mastitis was made on the basis of clinical examination of the udder by the veterinarian. Moreover, a quarter was identified as infected when somatic cell counts (SCC) were above 200 000/ml (Kot et al. 2012b). The quarter milk samples and the samples from the cowshed environment (the swabs from milker's hands, teat skin, teat cups milking machine, samples of cow's beddings, fodder and water) were collected in the eastern part of the Mazovia and the north Lublin region of Poland in years 2009-2010. The sampling methods, isolation and identification of staphylococcal isolates were described previously (Kot et al. 2012a).

\section{DNA isolation}

Genomic DNA was isolated from bacterial cells by using the IT $1-2-3^{\mathrm{TM}}$ DNA Sample Purification Kit (Idaho Technology Inc. Salt Lake City, Utah, USA) according to the manufacturer's protocol.

\section{Detection of enterotoxin genes}

The specific primers used in the present study are shown in Table 1 . The primers were synthesized by DNA-Gdańsk (Poland). Amplification of DNA was performed using the Multi Gene II thermal cycler (Labnet International, Inc., USA). PCR for enterotoxin genes was carried out under the following conditions: an initial denaturation of DNA at $95^{\circ} \mathrm{C}$ for $10 \mathrm{~min}$ was followed by 35 cycles of amplification $\left(95^{\circ} \mathrm{C}\right.$ for $30 \mathrm{~s}, 53^{\circ} \mathrm{C}$ for $45 \mathrm{~s}, 72^{\circ} \mathrm{C}$ for $\left.90 \mathrm{~s}\right)$, ending with a final extension at $72^{\circ} \mathrm{C}$ for $10 \mathrm{~min}$. Duplex PCR was performed with two different sets of primer mixtures: set 1: sea and seb, set 2: sec and sed. Monoplex PCR was used to detect the presence of the see gene. The volume of each PCR mixture was $25 \mu \mathrm{L}$ and contained $2.5 \mu \mathrm{L}$ of DNA template, $1 \times$ PCR buffer, 0.2 $\mathrm{mM}$ of dNTP mix (Fermentas, Lithuania), $200 \mathrm{nM}$ each primer, $1 \mathrm{U}$ of RedTag Genomic DNA polymerase (Sigma-Aldrich, Germany) and sterile deionized water. Positive controls with the genomic DNA from $S$. aureus for the sea, seb, sec, sed and see genes were included in each test run. All PCR 
Table 1. Nucleotide sequences of primers and expected size of PCR products (bp) of staphylococcal superantigenic toxins used in this study.

\begin{tabular}{|c|c|c|c|}
\hline Gene & Primer Oligonucleotides sequence $\left(5^{\prime}-3^{\prime}\right)$ & $\begin{array}{l}\text { PCR product } \\
\text { (bp) }\end{array}$ & References \\
\hline sea & $\begin{array}{l}\text { SEA-F CAGCATACTATATTGTTTAAAGGC } \\
\text { SEA-R CCTCTGAACCTTCCCATC }\end{array}$ & 400 & Park et al. 2011 \\
\hline$s e b$ & $\begin{array}{ll}\text { SEB-F } & \text { GTATGGTGGTGTAACTGAGCA } \\
\text { SEB-R } & \text { TCAATCTTCACATCTTTAGAATCA }\end{array}$ & 351 & Park et al. 2011 \\
\hline $\sec$ & $\begin{array}{ll}\text { SEC-F } & \text { CTCAAGAACTAGACATAAAAGCTAGG } \\
\text { SEC-R } & \text { TCAAAATCGGATTAACATTATCC }\end{array}$ & 271 & Becker et al. 1998 \\
\hline sed & $\begin{array}{ll}\text { SED-F } & \text { CTAGTTTGGTAATATCTCCTTTAAACG } \\
\text { SED-R } & \text { TTAATGCTATATCTTATAGGGTAAACATC }\end{array}$ & 319 & Becker et al. 1998 \\
\hline see & $\begin{array}{l}\text { SEE-F } \text { CAGTACCTATAGATAAAGTTAAAACAAG } \\
\text { SEE-R } \\
\text { CTAACTTACCGTGGACCCTTC }\end{array}$ & 178 & Becker et al. 1998 \\
\hline
\end{tabular}

(F) - forward primers, (R) - reverse primers.

Table 2. Distribution of enterotoxin genes among staphylococcal isolates.

\begin{tabular}{lccccc}
\hline & \multicolumn{5}{c}{ Results (no. of isolates) of PCR for: } \\
\cline { 2 - 6 } \multicolumn{1}{c}{ Species (n) } & sea & seb & sec & sed & see \\
\hline S. aureus $(\mathrm{n}=25)$ & $+(2)$ & $+(1)$ & $+(6)$ & $+(2)$ & - \\
S. xylosus $(\mathrm{n}=79)$ & - & - & $+(6)$ & $+(2)$ & $+(2)$ \\
S. sciuri $(\mathrm{n}=30)$ & - & - & $+(5)$ & - & - \\
S. epidermidis $(\mathrm{n}=29)$ & $+(1)$ & $+(1)$ & $+(2)$ & $+(1)$ & $+(1)$ \\
Staphylococcus spp. $(\mathrm{n}=22)$ & - & $+(3)$ & $+(2)$ & $+(1)$ & - \\
\hline Total $(185)$ & 3 & 5 & 21 & 6 & 3 \\
\hline
\end{tabular}

products were analysed by electrophoresis in $1.5 \%$ agarose gel stained with ethidium bromide in $2 \times$ Tris-borate-EDTA buffer. Molecular size marker (GenoPlast Biochemicals, Poland) was also run for product size verification.

\section{Results}

The presence of enetrotoxin genes sea, seb, sec, sed, see was investigated in 185 isolates including $25 \mathrm{~S}$. aureus and $160 \mathrm{CNS}$ originating from bovine milk and cowshed environmental samples. The presence of enterotoxin genes was detected in $8(32 \%) S$. aureus isolates in which two carried more than one gene encoding enterotoxins. Among CNS strains 22 (13.7\%) had enterotoxin genes. S. xylosus was the most prevalent CNS species and $9(11.4 \%)$ of the isolates were positive for enterotoxin genes. Six S. xylosus isolates from milk of cows with mastitis symptoms, two isolates from milk of cows without mastitis and one isolate originating from skin of milker's hands were positive for enterotoxin genes. In the case of $S$. sciuri and
S. epidermidis isolates the enterotoxin genes were detected in $5(16.7 \%)$ and $3(10.3 \%)$, respectively. In $S$. sciuri isolates only the sec gene was detected, present in 3 isolates from milk of cows with mastitis, one isolate originated from milk of cow without mastitis and one isolate from sample of cow's bedding. The isolates of $S$. epidermidis positive for enterotoxin genes originated from milk of cows with- and without mastitis. Among Staphylococcus spp. isolates 5 (22.7\%) were positive for enterotoxin genes. Most of isolates with genes encoding enterotoxins detected in staphylococci originated from milk of cows with mastitis symptoms $22(73.4 \%)$, while only $6(20 \%)$ isolates from milk of cows without mastitis symptoms, and one $(3.3 \%)$ isolate from the milker's hands and one (3.3\%) isolate from samples of cow's beddings were positive for enterotoxin genes. In some $S$. aureus, $S$. xylosus, and Staphylococcus spp. isolates sec + sed genes were detected simultaneously. The sea + seb genes were detected in one $S$. epidermidis isolate. Three genes sea $+s e b+s e c$ and $s e c+s e d+s e e$ were detected simultaneously in one $S$. aureus and $S$. epidermidis, respectively. The gene coding enterotoxin $\mathrm{C}$ was present 
A

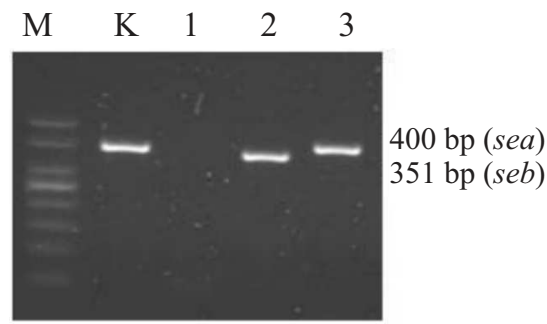

$\mathrm{B}$

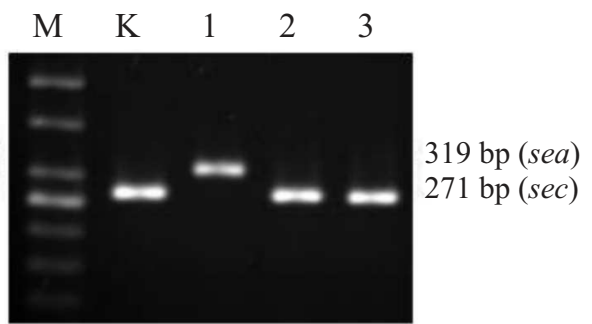

$\mathrm{C}$

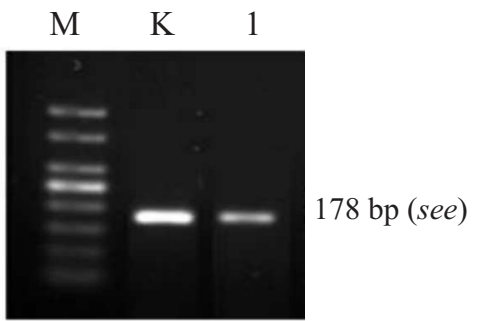

Fig. 1. Electrophoresis in 1.5\% agarose gel of PCR products obtained by using specific primers for sea and seb genes (A), sec and sed genes (B), see gene (C). A, B, C - Lanes M - molecular weight markers (500, 400, 300, 250, 200, 150, 100, 50 bp - GenoPlast Biochemicals). A - Lanes: K - 400 bp product obtained by using genomic DNA of $S$. aureus (positive control); 2 - product obtained by using genomic DNA of $S$. epidermidis isolate; 1 - no products by using genomic DNA of $S$. xylosus isolate; 2,3 - products obtained by using genomic DNA of $S$. epidermidis isolate. B - Lanes: K - 271 bp product obtained by using genomic DNA of $S$. aureus (positive control); 1 - product obtained by using genomic DNA of $S$. sciuri isolate; 2, 3 - products obtained by using genomic DNA of $S$. xylosus isolates. C - Lanes: K - 178 bp product obtained by using genomic DNA of $S$. aureus isolate; 1 -product by using genomic DNA of $S$. epidermidis isolate.

the most, $21(11.3 \%)$, of staphylococcal isolates (Table 2). The PCR product of $271 \mathrm{bp}$, corresponding to the fragment of the gene sec (Fig. 1B) was detected in $21(70 \%)$ of the isolates positive for enterotoxin genes. Among staphylococcal isolates having enterotoxin genes, the gene encoding enterotoxin D (amplification product of $319 \mathrm{bp}$ ) (Fig. 1B) was detected in $6(20 \%)$ isolates and gene encoding the enterotoxin B was present in genome of 5 isolates $(16.7 \%)$.

The lowest number of the tested isolates of staphylococci had genes sea and see because the products of $400 \mathrm{bp}$ specific for sea gene (Fig. 1A) were detected only in $3(10 \%)$ isolates, and fragments of $178 \mathrm{bp}$ corresponding to the see gene (Fig. 1C) were detected in other $3(10 \%)$ isolates (Table 2$)$.

\section{Discussion}

The family of toxins belonging to superantigens (SAgs) harbours staphylococcal exoprotein enterotoxins. Superantigenic toxins can cause lesions through the overproduction of cytotoxins by T-cells and by monocytes (Herman et al. 1991). Production of enterotoxins by staphylococci is an important virulence factor responsible for staphylococcal food poisoning (SFP) in humans. Major symptoms of staphylococcal intoxication such as vomiting, nausea, abdominal pain, diarrhea and headache occur after the ingestion of food contaminated with Staphylococcus produced enterotoxin. Clinical symptoms may be mild but sometimes they are serious and require hospitalization. Severity of intoxication depends on the amount of toxin ingested and individual susceptibility (Cunha and Calsolari 2008). Farm animals, particularly their milk, are considered a reservoir of enterotoxigenic staphylococcal species (Weese 2012). S. aureus is the most common pathogen of mastitis and milk is a good substrate for their growth. Several studies have shown that $S$. aureus isolates frequently contain SE genes and produce one or more enterotoxins that cause SFP in humans (Scherrer et al. 2004, Podkowik et al. 2013).

In our research $32 \%$ of $S$. aureus isolates were positive for enterotoxin genes which is in agreement with the results obtained by de Freitas Guimarãeses et al. (2013) who observed that $35 \%$ of coagulase-positive staphylococci from bovine milk had genes related to production of enterotoxins. Jørgensen et al. (2005) reported that sec gene was most commonly detected in $S$. aureus from bovine bulk milk in Norway which is consistent with our results. Boynukara et al. (2008), who examined $106 \mathrm{~S}$. aureus strains, found that $25.5 \%$ of them had enterotoxin genes, among which $23.5 \%$ were positive for sea and $1.9 \%$ were positive for seb genes. In our study, we also detected $S$. aureus isolates with sea and seb genes. Moreover, we detected isolates with sed gene and isolates with more than one enterotoxin gene, contrary to the results obtained by Boynukara et al. (2008), who did not obtain isolates positive for sec or sed genes or isolates with more than one type of enterotoxin gene.

Currently, the CNS are the most prevalent microorganisms isolated from milk samples of cows with mastitis symptoms and there are very little data on eterotoxigenic properties of CNS from bovine milk (Park et al. 2011, de Freitas Guimarães et al. 2013). In our study, $15.4 \%$ of CNS from bovine milk and $6.5 \%$ from cowshed environment were positive for enterotoxin genes. The highest percentage of CNS isolates with genes related to production of enterotoxins (66\%) was found by de Freitas Guimarãeses et al. (2013) who investigated CNS from bovine milk in Brazilian dairy herds. The differences in obtained 
results can by caused by spread of certain CNS types within specific geographical areas.

In this study, CNS isolates from cowshed environment carried only the sec gene and this gene also was detected most commonly in CNS from bovine milk, which is different from results obtained by Park et al. (2011), who showed that among the classical enterotoxins the seb gene was the most common in CNS isolates from bovine intramammary infections. Our results revealed that $\mathrm{sec}$ gene was detected in 15 (68.2\%) CNS isolates among 22 positive for enterotoxin genes. Lower percentage of CNS isolates with genes encoding the enterotoxin A $(4.5 \%), \mathrm{B}$ and D (18.2\%), E (13.6\%) were detected.

The SEs genes are diversely distributed among different CNS species (Park et al. 2011, de Freitas Guimarãeses et al. 2013). In our study, the enterotoxin genes were detected in 9 isolates of $S$. xylosus (11.4\%), 5 (16.7\%) of S. sciuri, $3(10.3 \%)$ of $S$. epidermidis and in $5(22.7 \%)$ of Staphylococcus spp.

Our results revealed that not only $S$. aureus isolates carry enterotoxin genes, but CNS isolated from bovine milk may be a source of these genes. Therefore, these microorganisms require more attention in microbiological evaluation of food and should not be considered mere contaminants.

\section{References}

Asao T, Kumeda Y, Kawai T, Shibata T, Oda H, Haruki K, Nakazawa H, Kozaki S (2003) An extensive outbreak of staphylococcal food poisoning due to low-fat milk in Japan: estimation of enterotoxin A in the incriminated milk and powdered skim milk. Epidemiol Infect 130: 33-40.

Baker MD, Acharya KR (2004) Superantigens: structurefunction relationships. Int J Med Microbiol 293: 529-537.

Bania J, Dąbrowska A, Bystroń J, Korzekwa K, Chrzanowska J, Molenda J (2006) Distribution of newly described enterotoxin-like genes in Staphylococcus aureus from food. Int J Food Microbiol 108: 36-41.

Becker K, Roth R, Peters G (1998) Rapid and specific detection of toxigenic Staphylococcus aureus: use of two multiplex PCR enzyme immunoassays for amplification and hybridization of staphylococcal enterotoxin genes, exfoliative toxin genes, and toxic shock syndrome toxin 1 gene. J Clin Microbiol 36: 2548-2553.

Blaiotta G, Fusco V, von Eiff C, Villani F, Becker K (2006) Biotyping of enterotoxigenic Staphylococcus aureus by enterotoxin gene cluster $(e g c)$ polymorphism and spa typing analyses. Appl Environ Microbiol 72: 6117-6123.

Boynukara B, Gulhan T, Alisarli M, Gurturk K, Solmaz H (2008) Classical enterotoxigenic characteristics of Staphylococcus aureus strains isolated from bovine subclinical mastitis in Van, Turkey. Int $\mathbf{J}$ Food Microbiol 125: 209-211.
Collery MM, Smyth DS, Twohig JM, Shore AC, Coleman DC, Smyth CJ (2008) Molecular typing of nasal carriage isolates of Staphylococcus aureus from an Irish university student population based on toxin gene PCR, agr locus types and multiple locus, variable number tandem repeat analysis. J Med Microbiol 57: 348-358.

Cunha ML, Calsolari RA (2008) Toxigenicity in Staphylococcus aureus and coagulase-negative staphylococci: epidemiological and molecular aspects. Microbiol Insights 1: 13-24.

De Freitas Guimarães F, Nóbrega DB, Richini-Pereira VB, Marson PM, Figueiredo Pantoja JC, Langoni H (2013) Enterotoxin genes in coagulase-negative and coagulase-positive staphylococci isolated from bovine milk. J Dairy Sci 96: 2866-2872.

Dinges MM, Orwin PM, Schlievert PM (2000) Exotoxins of Staphylococcus aureus. Clin Microbiol Rev 13: 16-34.

Herman A, Kappler JW, Marrack P, Pullen AM (1991) Superantigens: mechanism of T-cell stimulation and role in immune responses. Annu Rev Immunol 9: 745-772.

Jørgensen HJ, Mørk T, Høgåsen HR, Rørvik LM (2005) Enterotoxigenic Staphylococcus aureus in bulk milk in Norway. J Appl Microbiol 99: 158-166.

Kot B, Piechota M, Antos-Bielska M, Zdunek E, Wolska KM, Binek T, Olszewska J, Guliński P, Trafny EA (2012a) Antimicrobial resistance and genotypes of staphylococci from bovine milk and the cowshed environment. Pol J Vet Sci 15: 741-749.

Kot B, Piechota M, Wolska KM, Frankowska A, Zdunek E, Binek T, Kłopotowska E, Antosiewicz M (2012b) Phenotypic and genotypic antimicrobial resistance of staphylococci from bovine milk. Pol J Vet Sci 15: 677-683.

Lina G, Bohach GA, Nair SP, Hiramatsu K, Jouvin-Marche E, Mariuzza R (2004) Standard nomenclature for the superantigens expressed by Staphylococcus. J Infect Dis 189: 2334-2336.

Njage PM, Dolci S, Jans C, Wangoh J, Lacroix C, Meile $\mathrm{L}$ (2013) Biodiversity and enterotoxigenic potential of staphylococci isolated from raw and spontaneously fermented camel milk. Br Microbiol Res J 3: 128-138.

Orwin PM, Leung DY, Donahue HL, Novick RP, Schliewert PM (2001) Biochemical and biological properties of staphylococcal enterotoxin K. Infect Immun 69: 360-366.

Park JY, Fox LK, Seo KS, McGuire MA, Park YH, Rurangirwa FR, Sischo WM, Bohach GA (2011) Detection of classical and newly described staphylococcal superantigen genes in coagulase-negative staphylococci isolated from bovine intramammary infections. Vet Microbiol 147: 149-154.

Podkowik M, Park JY, Seo KS, Bystroń J, Bania J (2013) Enterotoxigenic potential of coagulase-negative staphylococci. Int J Food Microbiol 163: 34-40.

Sampimon OC, Barkema HW, Berends IM, Sol J, Lam TJ (2009) Prevalence and herd-level risk factors for intramammary infection with coagulase-negative staphylococci in Dutch dairy herds. Vet Microbiol 134: 37-44.

Scherrer D, Corti S, Muehlherr JE, Zweifel C, Stephan R (2004) Phenotypic and genotypic characteristics of Staphylococcus aureus isolates from raw bulk-tank milk samples of goats and sheep. Vet Microbiol 101: 101-107.

Weese JS (2012) Staphylococcal control in the veterinary hospital. Vet Dermatol 23: 292-298. 